\title{
Characterization of Escherichia coli MG 1655 grown in a low-shear modeled microgravity environment
}

\author{
Don L Tucker ${ }^{1,2}$, C Mark Ott ${ }^{2}$, Stephen Huff ${ }^{3}$, Yuriy Fofanov ${ }^{1,3}$, \\ Duane L Pierson ${ }^{2}$, Richard C Willson ${ }^{1,4}$ and George E Fox*1,4
}

\begin{abstract}
Address: ${ }^{1}$ University of Houston, Department of Biology \& Biochemistry, 369 Science and Research Bldg. \#2, Houston, TX 77204-5001, USA, 2NASA Johnson Space Center, Habitability and Environmental Factors Office, Houston, TX, 77058, USA, ${ }^{3}$ University of Houston, Department of Computer Science, Houston, TX, 77204-3010 USA and ${ }^{4}$ University of Houston, Department of Chemical Engineering, Houston, TX, 77204-4004, USA

Email: Don L Tucker - dtucker84@yahoo.com; C Mark Ott - c.m.ott@nasa.gov; Stephen Huff - epsilon3@bioinfo.uh.edu; Yuriy Fofanov - yfofanov@bioinfo.uh.edu; Duane L Pierson - duane.l.pierson@nasa.gov; Richard C Willson - rcwwww@gmail.com; George E Fox* - fox@uh.edu

* Corresponding author
\end{abstract}

Published: 7 March 2007

BMC Microbiology 2007, 7:15 doi:10.1/86/147|-2/80-7-15
Received: 5 October 2006

Accepted: 7 March 2007

This article is available from: http://www.biomedcentral.com/I47I-2/80/7//5

(c) 2007 Tucker et al; licensee BioMed Central Ltd.

This is an Open Access article distributed under the terms of the Creative Commons Attribution License (http://creativecommons.org/licenses/by/2.0), which permits unrestricted use, distribution, and reproduction in any medium, provided the original work is properly cited.

\begin{abstract}
Background: Extra-cellular shear force is an important environmental parameter that is significant both medically and in the space environment. Escherichia coli cells grown in a low-shear modeled microgravity (LSMMG) environment produced in a high aspect rotating vessel (HARV) were subjected to transcriptional and physiological analysis.

Results: Aerobic LSMMG cultures were grown in rich (LB) and minimal (MOPS + glucose) medium with a normal gravity vector HARV control. Reproducible changes in transcription were seen, but no specific LSMMG responsive genes were identified. Instead, absence of shear and a randomized gravity vector appears to cause local extra-cellular environmental changes, which elicit reproducible cellular responses. In minimal media, the majority of the significantly up- or downregulated genes of known function were associated with the cell envelope. In rich medium, most LSMMG down-regulated genes were involved in translation. No observable changes in post-culture stress responses and antibiotic sensitivity were seen in cells immediately after exposure to LSMMG. Comparison with earlier studies of Salmonella enterica serovar Typhimurium conducted under similar growth conditions, revealed essentially no similarity in the genes that were significantly upor down-regulated.

Conclusion: Comparison of these results to previous studies suggests that different organisms may dramatically differ in their responses to medically significant low-shear and space environments. Depending on their specific response, some organisms, such as Salmonella, may become preadapted in a manner that predisposes them to increased virulence.
\end{abstract}

\section{Background}

Bacteria are capable of living in and adapting to a far larger range of environmental conditions than are normally encountered in the usual laboratory environments. Even with full knowledge of an organism's gene content, it is currently impossible to predict how expression patterns 
will change in different situations. Thus, usual laboratory growth conditions may not invoke key aspects of an organism's potential response and thereby such studies may conceal behaviors that in a different environment may contribute to undesirable phenomena such as pathogenesis. One such case is the low-shear, low-turbulence environments present in utero, at the brush border microvilli of epithelial cells, and other medically important host environments [1].

Research in this medically important host environment has been greatly aided by the development of High Aspect Rotating Vessel (HARV) bioreactors, which can produce a unique Low-Shear Modeled Microgravity (LSMMG) environment. The solid body rotation of the HARV was designed to randomize the gravity vector and minimize the effect of fluid shear on the surface of the cell when rotated in the plane of gravity, producing the LSMMG environment [2]. To obtain the solid body rotation, the HARV device is completely filled to prevent gas bubbles, which cause solution turbulence (i.e. mixing) and associated shear. This type of LSMMG environment has been investigated extensively with mammalian cellular systems as it also mimics several aspects of the environment encountered during space flight [3]. A HARV bioreactor rotated perpendicular to the plane of gravity was employed as a control for maintaining a constant gravity vector and cell surface shear from settling. The application of HARV bioreactors as an analogue for medical and space environments, as well as the benefits and constraints imposed by rotating bioreactors, has been described in detail in a review by Nickerson et al. [2].

Bacterial physiology in HARV grown cultures, used in conjunction with commercially available functional genomic technology, makes it possible to study the microbial responses to LSMMG at the genomic level. A recent study has shown that LSMMG grown Salmonella enterica serovar Typhimurium (S. Typhimurium) displayed increased virulence in a murine model system, as well as an increased ability to withstand antimicrobial defenses of host macrophages, and an increased resistance to acid stress. This strain had 38 proteins down-regulated in LSMMG compared to the normal gravity vector control [4]. A follow-up study revealed 163 genes transcriptionally regulated in response to LSMMG [5]. The changes seen in S. Typhimurium in response to LSMMG, compared to an environment with gravity-induced shear, illustrate the potential for medically significant bacterial responses in non-standard host environments.

Based on the previous work in $S$. Typhimurium [4,5], we herein describe a broader comparison of Escherichia coli MG1655 to determine the effect of medium on global gene regulation and physiology allowing identification of medium independent LSMMG responses and gene regulation. E. coli MG1655 was chosen as a model system for comparison to $S$. Typhimurium based on: the availability of the complete genomic sequence [6], commercially produced genomic arrays, a well-characterized knowledge of E. coli's metabolism and gene regulation $[7,8]$ and it's genomic sequence similarity to $S$. Typhimurium [9]. More is known about $E$. coli and $S$. Typhimurium than about any other forms of cellular life and they resemble each other closely, both being Gram-negative rods of the family Enterobacteriaceae [8].

Our analysis of E. coli MG1655 in LSMMG encompassed physiology, stress resistance and transcriptional analysis in both rich and minimal medium. This facilitated comparison to the rich medium LSMMG responses previously reported in $S$. Typhimurium $[5,10]$. Functional genomic macro-array analysis of LSMMG and control samples was employed to identify the LSMMG responsive genes and operons present in E. coli MG1655. For this analysis, the mid-log phase of growth was selected for RNA harvest with subsequent functional genomic analysis because it is a comparable physiological state between experimental replicates [11]. The responses of E. coli MG1655 to the unique LSMMG environment present in HARV bioreactors were compared to those seen in the closely related bacteria $S$. Typhimurium $[4,5]$. We had hoped to identify related responses and transcriptional regulation in common between $E$. coli and $S$. Typhimurium, possibly indicating Gram-negative bacterial adaptation systems which react to LSMMG. The E. coli MG1655 LSMMG data presented in this report did not permit identification of common bacterial response systems and indicated instead species (and possibly strain) specific responses and/or medium dependent responses to LSMMG.

\section{Results \\ LSMMG grown E. coli MGI655 physiology}

The lag time for LSMMG and the control cultures in LB was $173 \pm 10$ minutes and $172 \pm 10$ minutes, respectively. As expected, the lag phase in minimal MOPS medium was longer than that seen in LB medium, with the LSMMG and control MOPS cultures having lag phases of $452 \pm 19$ minutes and $454 \pm 19$ minutes, respectively. E. coli exponential growth in minimal MOPS medium was similar between LSMMG and the control with maximum average doubling times of $76.3 \pm 10$ minutes and $76.8 \pm 11$ minutes, respectively. In contrast in rich LB medium, growth in LSMMG was slower than the control with doubling times of $34.7 \pm 4.7$ and $43.8 \pm 8.9$ minutes respectively. In rich medium, elapsed time between culture inoculation \& RNA harvest was highly reproducible, with both LSMMG and $1 \times \mathrm{g}$ control samples reaching an OD600 $=0.5$ at 265 $+/-5$ minutes. In minimal medium, LSMMG and $1 \times \mathrm{g}$ control samples reached an OD600 $=0.4$ for RNA harvest 
at $564+/-30$ minutes. Growth curves are provided as additional materials [see additional files 1 and 2]

\section{Medium physiochemical composition during growth}

Initially, there was concern that changes in gene expression were caused by physiochemical differences between LSMMG and control cultures. Slight variations of medium components such as $\mathrm{O}_{2}$ can produce extremely divergent cellular responses [12]. Component analysis of both LB and MOPS medium was performed to analyze $\mathrm{O}_{2}, \mathrm{CO}_{2}$ and glucose concentrations as well as medium $\mathrm{pH}$ during HARV culture growth. HARV $\mathrm{O}_{2}$-concentration in rich medium, both LSMMG and control, dropped by $28 \pm$ $12.8 \%$. In minimal medium, $\mathrm{O}_{2}$ content decreased by 10 $\pm 13.1 \%$ in both growth conditions. The level of $\mathrm{CO}_{2}$ in MOPS cultures remained immeasurably low, but the faster growing rich medium cultures accumulated $\mathrm{CO}_{2}$ in a comparable manner in both samples. Physiochemical analysis revealed no significant difference in $\mathrm{pH}, \mathrm{O}_{2}, \mathrm{CO}_{2}$, and glucose concentrations between LSMMG and the control in either rich LB or minimal MOPS medium.

\section{Stress survival analysis}

Previous reports had revealed that short term exposure to LSMMG enhanced thermal and acidic stress resistances in $S$. Typhimurium and enhanced osmotic and acid stress resistances in E. coli AMS6 [4,10,13]. For comparison to these organisms and to determine if LSMMG enhanced the survival capabilities of E. coli MG1655, antibiotic resistance and stress survival assays in both rich and minimal medium were performed. Unlike $S$. Typhimurium and E. coli AMS6, no significant differences in E. coli MG1655 antibiotic resistances or stress survivals between LSMMG and the control were identified in this analysis. The detailed data is included on the project web site [14] and here as supplementary material [see additional file 3]. A preliminary experiment with $E$. coli MG1655 grown in the presence of ampicillin also indicated no apparent growth effect in LSMMG.

\section{Functional genomic analysis of MOPS LSMMG grown E. coli cultures}

Statistical analysis identified 16 up-regulated and 19 down-regulated genes in LSMMG (Tables 1 and 2) compared to the control during the mid-log phase of growth in minimal MOPS medium. Of these, 1 up-regulated and 8 down-regulated genes coded for hypothetical proteins. Among the up-regulated genes of known or putative function in LSMMG are genes involved in the E. coli acid tolerance response [transcriptional regulator gadE [15], the putative chaperone hdeA [16] and associated genes hdeB, $h d e D$ and $d c t R$ [17]], flg and fli genes involved in cell motility [18], chemotaxis regulating genes, cheZ and tar [19], and the phage related gene $y d f D$ [20] (Table 1).
Among the MOPS LSMMG down-regulated genes (Table 2) were five genes associated with heavy metal efflux (CusCFBA and $\operatorname{copA}$ ) [21]. Other LSMMG down-regulated genes included four putative bacteriaphage lambda homologs [20], 4 genes involved in various stress responses [22-25], the drug resistance gene emrE [26], and the acetylCoA carboxylase subunit accB [27] (Table 2). Two of the MOPS LSMMG down-regulated genes ( $c p x P$ and $\gamma f i A$ ) were regulators. CpxP serves as repressor of the Cpx envelope/extracytoplasmic toxicity stress response system [22,23], protects the cell from toxic, transitory stresses [28], is involved in adhesion and virulence of pathogenic E. coli [29], and may also act as a periplasmic chaperone [30]. Yfia stabilizes 30S rRNA under cold shock conditions [24]. Possible co-transcribed genes of putative operons were identified based on genomic location and orientation (Tables 1 and 2, Cotran column). Physical mapping of the LSMMG MOPS regulated genes found 27 of 35 genes in 4 gene clusters with the remaining regulated genes distributed throughout the E. coli genome (Fig. 1).

\section{Functional genomic analysis of rich media LSMMG E. coli MGI 655 cultures}

Statistical analysis employing all of the criteria described above on the LB LSMMG cultures only identified 14 down-regulated genes in LSMMG compared to the control (Table 3). The extremely low number of LB LSMMG regulated genes, for later comparison to $S$. Typhimurium (see discussion) led us to consider additional genes that met the criteria of a p-value $<0.05$ and $>3$ standard deviations of expression in only 2 of the 3 LB biological replicates with similar expression in the $3^{\text {rd }}$ replicate (Table 3 ). Under this reduced stringency, the carboxyl transferase subunit gene accA was found to be up-regulated in LB LSMMG (Table 3) [31].

E. coli LB LSMMG down-regulated genes, that met the significance criteria in all 3 LB biological replicates (Table 3) were mostly involved in biosynthesis and energy utilization. Down-regulated rRNA associated genes included six $50 \mathrm{~S}$ and three $30 \mathrm{~S}$ ribosomal protein genes [32] and the rim $M$ gene required for $16 \mathrm{~S}$ rRNA processing [33]. Additional LB LSMMG down-regulated genes included genes involved in energy production or catabolism (apt and $s u c D[20,34])$, the ribose transporter $r b s D$, the tRNA methyltransferase trmD [35], and the ORF $y p j D$. Putative operons were identified (Table 3, Cotran column) and physical mapping revealed 8 of 15 genes in 2 gene clusters (Fig. 2).

\section{Transcriptional comparison of MOPS and LB grown E. coli MGI 655 cultures}

No genes were identified that responded in the same manner to LSMMG in both minimal MOPS and rich LB 
Table I: LSMMG E. coli MGI655 genes up-regulated compared to the control in minimal MOPS medium.

\begin{tabular}{|c|c|c|c|c|c|c|c|}
\hline Gene & b\# & Contran & Ave. Fold Change & $\begin{array}{l}\text { Average } \\
\text { p-value }\end{array}$ & Gene Product & Product Location & $\begin{array}{l}\text { Present in } S \text {. } \\
\text { Typhimurium }\end{array}$ \\
\hline$f \lg B$ & bl073 & yes & 2.15 & 0.0043 & flagellar biosynthesis, basal-body rod & periplasm & present \\
\hline$f \lg D$ & bl075 & yes & 2.00 & 0.0013 & flagellar biosynthesis, initiation of hook assembly & membrane & present \\
\hline flgE & bl076 & yes & 2.43 & 0.0002 & flagellar biosynthesis, hook protein & membrane & present \\
\hline flgK & bl082 & & 2.01 & 0.0007 & flagellar biosynthesis, hook-filament junction protein & membrane & present \\
\hline$f x A$ & b|566 & & 2.14 & 0.0215 & orf, hypothetical protein (member of FliA regulon) & membrane & \\
\hline$y d f D$ & bl576 & & 3.75 & 0.0003 & prophage \& phage related function (Qin prophage) & & \\
\hline$\underline{c h e Z}$ & b| 881 & yes & 2.02 & 0.0032 & chemotactic response; CheY protein phophatase & membrane & present \\
\hline$\underline{\operatorname{tar}}$ & bl886 & ? & 2.02 & 0.0006 & methyl-accepting chemotaxis protein II, sensor receptor & inner mem. & present \\
\hline$f l i Z^{*}$ & bl921 & yes & 2.25 & 0.0007 & putative cell-density sigmaF response regulator & cytoplasm & present \\
\hline flic & bl923 & yes & 2.30 & 0.0155 & flagellar biosynthesis; filament structural protein & membrane & present \\
\hline$f l i D$ & bl924 & & 2.06 & 0.0025 & flagellar biosynthesis; filament capping protein & membrane & present \\
\hline$\underline{\operatorname{dct} R^{*}}$ & b3507 & & 2.57 & 0.0006 & acid tolerance, dicarboxylate transport, 0157 adhesion & cytoplasm & \\
\hline$\underline{h d e B}$ & b3509 & yes & 6.34 & 0.0006 & hdeA homolog, related to $S$. flexneri acid protein & periplasm & orthologue \\
\hline$\underline{h d e A}$ & b3510 & yes & 4.43 & 0.0013 & acid resistance protein, putative chaperone & periplasm & orthologue \\
\hline$\underline{\text { hdeD }}$ & b35II & & 3.54 & 0.0003 & acid resistance protein & putative mem. & \\
\hline $\operatorname{gadE}{ }^{*}$ & b3512 & & 2.58 & 0.0036 & acid-responsive GadABC regulator, 0157 adhesion & cytoplasm & \\
\hline
\end{tabular}

Ave. Fold Change and Average p-value columns are the averaged fold change in gene expression and p-values from the 3 MOPS minimal media functional genomic experiments.

*Gene product located in cytoplasm, but plays a role in membrane component regulation.

Underlined: associated or involved in membrane function, production or regulation.

medium (Tables 1, 2 and 3). This remained true even under reduced statistical stringency.

\section{RT-PCR of selected LSMMG regulated genes}

Reverse Transcription - Polymerase Chain Reaction (RTPCR) of selected genes was performed to verify the differential expression seen on arrays between LSMMG and the control in both MOPS minimal and rich LB medium (Fig. 3). RT-PCR primers were developed to specifically amplify LSMMG responding genes identified in the genomic array analysis. All of the RT-PCR results, for operons $h d e A B$ and
flgBCDE (MOPS LSMMG up-regulated), tdcDEFG (LB LSMMG up-regulated) and $r p s F-p r i B-r p s R$-rplI (LB LSMMG down-regulated), are consistent with the whole genome array data and support the LSMMG induced transcriptional regulation described above (Fig. 3).

\section{Promoter search analysis}

A manual examination of putative transcriptional regulator binding sites upstream of LSMMG regulated genes and operons (from both minimal and rich medium) did not

Table 2: LSMMG E. coli MGI655 genes down-regulated compared to the control in minimal MOPS medium.

\begin{tabular}{|c|c|c|c|c|c|c|c|}
\hline Gene & b\# & Contran & $\begin{array}{l}\text { Ave. Fold } \\
\text { Change }\end{array}$ & Average $\mathrm{p}$-value & Gene Product & Product Location & $\begin{array}{l}\text { Present in } S . \\
\text { Typhimurium }\end{array}$ \\
\hline yaiN & b0357 & & -2.28 & 0.0013 & orf, hypothetical protein & & orthologue \\
\hline copA & b0484 & & -2.21 & 0.0012 & Cu-translocating P-type ATPase resistance pump & inner mem. & present \\
\hline renD & b0542 & yes & -2.02 & 0.0005 & orf, phage $\lambda$ ren gene homolog & lysis & \\
\hline emrE & b0543 & yes & -2.02 & 0.0001 & multidrug resistance pump, methylviologen resistance & inner mem. & orthologue \\
\hline$\underline{\text { ess } D}$ & b0554 & yes & -2.57 & 0.0001 & orf, phage lambda S lysis protein homolog & mem. lysis & \\
\hline$y b c S$ & b0555 & yes & -2.19 & 0.0001 & orf, bacteriophage lambda lysozyme homolog & wall lysis & orthologue \\
\hline$\underline{\operatorname{rzpD}}$ & b0556 & yes & -2.41 & 0.0001 & orf, bacteriophage lambda endopeptidase homolog & mem. disrpt. & orthologue \\
\hline $\mathrm{ybcH}$ & b0567 & & -3.17 & 0.0000 & orf, hypothetical protein & & \\
\hline$\underline{\text { cusC }}$ & b0572 & yes & -2.57 & 0.0002 & outer mem. factor of CusABC $\mathrm{Ag} \& \mathrm{Cu}$ efflux system & outer mem. & orthologue \\
\hline cusF & b0573 & yes & -4.06 & 0.0001 & $\mathrm{Ag} \& \mathrm{Cu}$ periplasmic binding protein, chaperone & periplasm & \\
\hline CusB & b0574 & yes & -2.16 & 0.0001 & CusABC $\mathrm{Ag} \& \mathrm{Cu}$ efflux periplasmic fusion protein & periplasm & \\
\hline cusA & b0575 & yes & -3.26 & 0.0001 & inner mem. factor of CusABC $\mathrm{Ag} \& \mathrm{Cu}$ transporter & inner mem. & orthologue \\
\hline$\overline{y b d F}$ & b0579 & & -2.47 & 0.0005 & orf, hypothetical protein & & \\
\hline uspG & b0607 & & -2.55 & 0.0003 & universal stress protein of UspA family, heat shock & cytoplasm & present \\
\hline yfiA & b2597 & & -2.50 & 0.0007 & 30 S ribosome stabilizing subunit, cold shock response & cytoplasm & present \\
\hline$a_{c c B}^{*}$ & b3255 & & -2.64 & 0.0001 & acetylCoA carboxylase, BCCP subunit; fatty acid bios. & cytoplasm & present \\
\hline$c p x P$ & b3913/14 & & -2.50 & 0.0002 & Cpx extracytoplasmic stress response repressor & periplasmic & present \\
\hline yjaH & b400I & & -2.32 & 0.0021 & orf, hypothetical protein & & present \\
\hline$\underline{z r a P}$ & b4002 & & -3.84 & 0.0000 & zinc binding periplasmic protein, responds to $\mathrm{Zn} \& \mathrm{~Pb}$ & periplasm & present \\
\hline
\end{tabular}

Ave. Fold Change and Average $p$-value columns are the averaged fold change in gene expression and $p$-values from the 3 MOPS minimal media functional genomic experiments.

*Gene product located in cytoplasm, but plays a role in membrane component regulation.

Underlined: associated or involved in membrane function, production or regulation. 


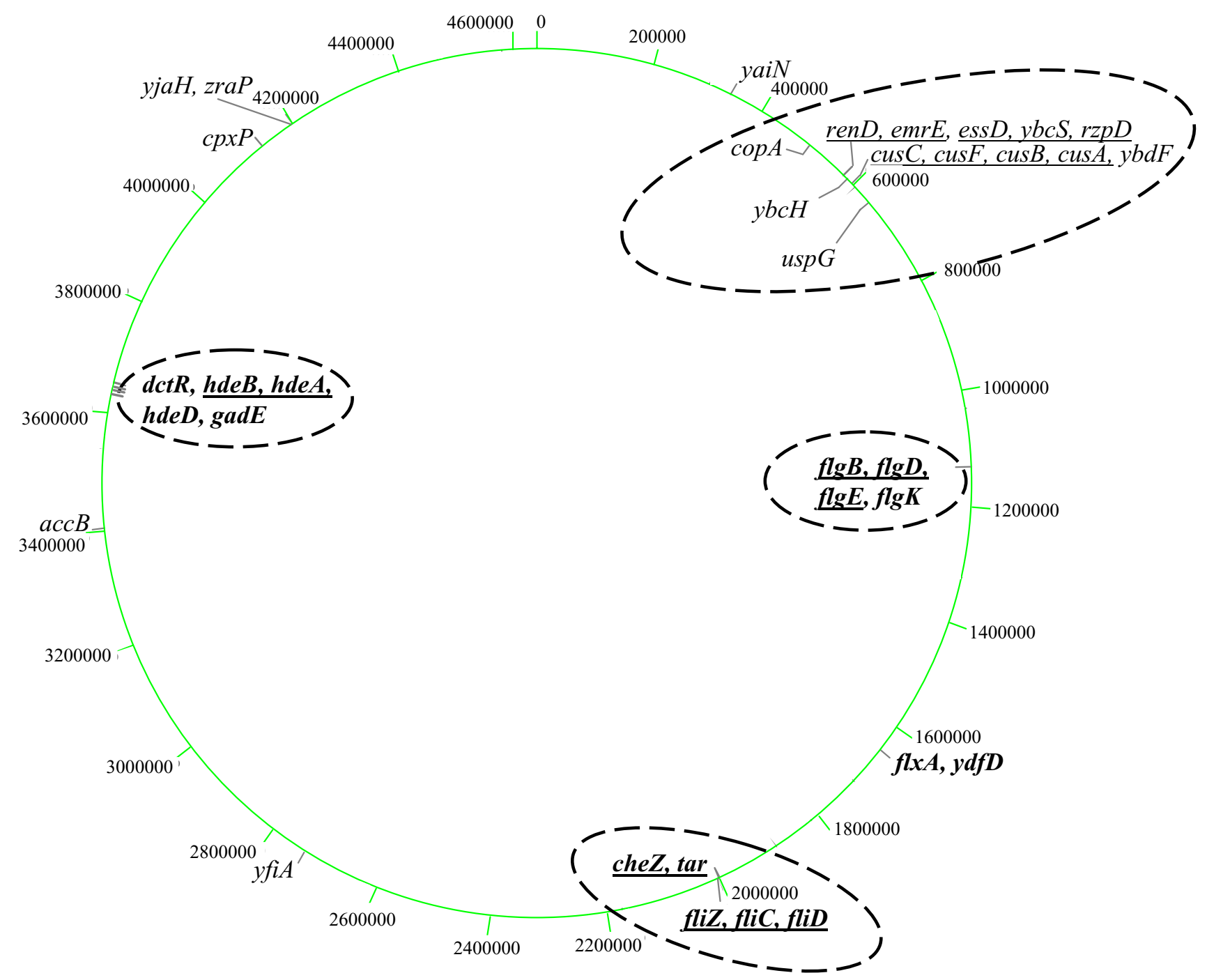

Figure I

Schematic representation of the circular E. coli MG 655 chromosome with kilobase coordinates indicated. LSMMG up-regulated genes in MOPS minimal medium are in bold and down-regulated genes are in regular case. In this figure, commas between gene names indicate gene proximity in the $E$. coli genome. Underlined genes are likely co-transcribed. The dashed ovals indicate gene clusters.

reveal any conserved sequence motifs potentially regulated by LSMMG.

\section{Discussion}

Hybridization arrays revealed reproducible transcriptional differences when cultures grown on either rich or minimal media in the HARV bioreactor in LSMMG were compared to the control orientation. In order to eliminate the technical variation caused by array versus array and spot vs. spot difference, an experimental plan was designed in such way that every control and experiment was performed using the same physical microarray. Such a design has all the advantages of the two color microarrays and allows one after normalization to perform analysis of the changes (ratios) in the expression signals between control and experiment for each individual spot on the microarray. Rigorous statistical criteria were applied to determine which genes were significantly up or down regulated in the individual experiments. A separate statistical analysis of the false positive rate was undertaken 
and this rate was less than two genes in the worse case. Direct examination of relative mRNA levels by RT-PCR confirmed the array results.

Measurement of HARV $\mathrm{O}_{2}$ concentration during E. coli MG1655 growth indicated that while $\mathrm{O}_{2}$ content decreased inversely to culture density, it never approached anaerobic conditions. In addition, comparisons of $\mathrm{O}_{2}$ concentrations between LSMMG and the control did not differ during growth in either minimal MOPS or rich LB medium (data not shown). Differences in $\mathrm{pH}, \mathrm{CO}_{2}$, and minimal MOPS medium glucose concentrations between LSMMG and the control were also not statistically distinguishable (data not shown). Thus, these factors are unlikely to account for observed differences in transcription that are seen in LSMMG compared to control cells.

Culture growth kinetics were used to determine if LSMMG altered E. coli MG1655 physiology in a growth dependent manner [36]. It is noteworthy that while E. coli MG1655 responds to LSMMG at the level of transcriptional regulation, cellular physiology was only affected in rich LB medium where a decreased exponential growth rate compared to the control was observed. This is in contrast to $S$. Typhimurium, where rich medium growth rates were largely unchanged and the minimal medium LSMMG doubling time was 25-30 minutes faster than the control [10].

The primary differences between the LSMMG environment and the control are the randomized gravity vector and low shear present in LSMMG. In attempting to interpret the differences seen, one must consider that they might be due to either or both of these factors or as an indirect effect of one or both. If a direct response to gravity were occurring, one would, for example, expect the effect to be repeated in all growth or media conditions in which the gravity vector was randomized. The results presented here instead identify only medium specific E. coli MG1655 genes that are either up- or down-regulated in the LSMMG environment.

In minimal MOPS medium, chemotactic and flagellar genes (Table 1) as well as genes involved in the E. coli acid tolerance response [17] were up-regulated in LSMMG. The reason for up-regulation of acid tolerance response genes in LSMMG grown E. coli MG1655 remains unclear, but it is noteworthy that LSMMG grown $S$. Typhimurium has an increased resistance to acid shock [10] that is not seen in E. coli MG1655. It is attractive to theorize that the LSMMG up-regulation of flagellar and chemotactic genes in minimal medium is related to a cellular requirement for relocation away from zones of local nutrient depletion and excreted waste hypothesized to occur in the low mixing environment of space [37]. However, no data was col- lected to address the question of whether or not an increase in actual motility occurred. Thus, although this is an attractive hypothesis, the presence of these zones in HARV produced LSMMG and whether or not E. coli MG1655 is responding to these zones by up-regulating flagellar and the chemotactic genes requires further study. The majority of minimal medium LSMMG down-regulated genes (Table 2) are involved in metal or drug transport, cell lysis, or in regulating cellular stress responses, which alludes to the importance of the cell envelope in regulating the LSMMG response in minimal medium grown E. coli MG1655. More generally, all of the LSMMG up-regulated genes and a majority of the down-regulated genes of known function are present in or involved with regulation of the cellular envelope (Table 1 \&2). This suggests that the cell envelope is superlative in sensing changes in its local environment and able to rapidly respond to the changes in a multifaceted way. Future time course studies of the LSMMG response to minimal media in cells pre-adapted to the HARV control environment may allow detailed study of how the genes involved are coordinated.

In rich medium, the majority of the E. coli MG1655 genes that respond to the LSMMG environment are down-regulated, present in the cytoplasm, and involved in translation (Table 3). In addition, several other ribosomal protein genes, including L2, L5, L7/L12 and L18 passed at least one statistical test and therefore may be down regulated as well. Because ribosomes accumulate in a growth rate dependent matter, this apparent down regulation more likely is just a delay in the accumulation of translation related mRNAs reflecting the slower growth of the LSMMG cultures relative to the control that was detected in the growth rate studies.

$S$. Typhimurium is an evolutionarily close relative of $E$. coli and its response to LSMMG has been studied previously $[5,10]$. In fact, the majority of the E. coli MG1655 LSMMG up- and down-regulated genes have homologues or orthologues in S. Typhimurium (Tables 1,2 and 3). We therefore sought to compare our results to these earlier studies. It was immediately obvious that many more genes were reported to be responding to LSMMG in rich medium grown $S$. Typhimurium than in E. coli MG1655. Much of this difference was clearly the result of the statistical criteria used. To facilitate comparison, the E. coli MG1655 transcriptional data was re-analyzed using the exact statistical methods employed previously for $S$. Typhimurium [5]. This second analysis of the E. coli data identified essentially the same up- and down-regulated genes already described, as well as a number of additional genes (data not shown). Most of the additional E. coli MG1655 genes were not considered further because of a very low level of gene expression in both LSMMG and control cul- 
Table 3: E. coli MGI655 LSMMG regulated genes in rich (LB) medium.

\begin{tabular}{|c|c|c|c|c|c|c|c|}
\hline \multicolumn{8}{|c|}{ LSMMG up-regulated genes } \\
\hline Gene & b\# & Contran & $\begin{array}{l}\text { Ave. Fold } \\
\text { Change }\end{array}$ & Average p-value & Gene Product & Product Location & $\begin{array}{l}\text { Present in } S . \\
\text { Typhimurium }\end{array}$ \\
\hline$\underline{a c c A}$ & b0185 & & 2.05 & 0.2873 & acetyl-coenzyme A carboxylase & cytoplasm & present \\
\hline \multicolumn{8}{|c|}{ LSMMG down-regulated genes } \\
\hline$a p t$ & b0469 & & -2.22 & 0.0005 & adenine phosphoribosyltransferase, adenine salvage & cytoplasm & present \\
\hline sucD & b0729 & & -2.15 & 0.0001 & succinyl-coA synthetase alpha subunit & cytoplasm & present \\
\hline$r p / Y$ & b2185 & & -7.57 & 0.0506 & 50 S ribosomal subunit protein L25 & cytoplasm & present \\
\hline$r p / S$ & b2606 & yes & -2.99 & 0.0597 & $50 S$ ribosomal subunit protein LI9 & cytoplasm & present \\
\hline $\operatorname{trm} D$ & b2607 & yes & -2.59 & 0.0211 & tRNA (guanine-I) methyltransferase & cytoplasm & present \\
\hline $\operatorname{rim} M$ & b2608 & yes & -2.67 & 0.0024 & protein required for wild-type $16 \mathrm{~S}$ rRNA processing & cytoplasm & present \\
\hline rpsP & b2609 & yes & -3.38 & 0.0046 & $30 S$ ribosomal subunit protein $\mathrm{SI} 6$ & cytoplasm & present \\
\hline ypjD & b26II & & -2.26 & 0.0011 & ORF, putative membrane protein & membrane orthologue & \\
\hline rplU & b3186 & & -2.41 & 0.0006 & $50 S$ ribosomal subunit protein L2I & cytoplasm & present \\
\hline rplA & b3984 & yes & -5.33 & 0.0538 & 50 S ribosomal protein II & cytoplasm & present \\
\hline rpll & b3985 & yes & -6.05 & 0.0542 & $50 S$ ribosomal subunit protein LIO & cytoplasm & present \\
\hline rpsF & b4200 & yes & -3.09 & 0.0003 & $30 S$ ribosomal subunit protein S6 & cytoplasm & present \\
\hline$r p s R$ & b4202 & yes & -3.31 & 0.0174 & $30 S$ ribosomal subunit protein SI 8 & cytoplasm & present \\
\hline rpll & b4203 & yes & -2.81 & 0.0123 & 50 S ribosomal subunit protein L9 & cytoplasm & present \\
\hline
\end{tabular}

Ave. Fold Change column average of 3 experiments and Average p-value column average p-values from the 2 rich LB media functional genomic experiments.

Underlined: associated or involved in membrane function, production or regulation.

tures, which greatly increased the possibility of false-positive results [38].

LSMMG and control gene expression ratios for E. coli MG1655 (this study) and those of S. Typhimurium [5] were further compared to identify shared genes and operons that responded to LSMMG in a similar manner. Surprisingly, E. coli genes that were up-regulated in LSMMG with the highest expression ratios were either not detectable in $S$. Typhimurium [5] or had a LSMMG fold change expression ratio $<2$ (Table 4). Similarly, $S$. Typhimurium genes with the greatest expression ratios in LSMMG, with the exception of $s u c D$, were not significantly up-regulated in E. coli MG1655 under LSMMG conditions (Table 5). The gene $s u c D$, which encodes a succinyl-CoA synthase, was down-regulated in both organisms in rich medium (Table 4 and 5) [5,13].

For both rich and minimal medium, a greater number of genes were down-regulated in response to LSMMG in $E$. coli MG1655. Although only rich media was examined in detail in the case of $S$. Typhimurium, the same pattern was observed [5]. In addition, many of the genes in E. coli MG1655 that responded to LSMMG conditions were clustered in known or likely operons (Fig. 1 and 2) and this pattern was also seen in S. Typhimurium [5]. However, when individual genes were intercompared, it was abundantly clear that the vast majority of genes affected by LSMMG in E. coli MG1655 and S. Typhimurium were not affected in the same manner in the other organism. $S$. Typhimurium may be responding to LSMMG in part by activating genes involved in pathogenicity and adhesion in an attempt to promote colonization in the low-shear environment. The consequences of this may be that $S$. Typhimurium cells, although likely not genetically altered, are predisposed to the virulence state due to their attempt to adapt their gene expression to the LSMMG environment. This may explain why they are more infective in mice than cells not exposed to LSMMG [27].

Certainly, genetic variation between and within species [39] and even variations between different laboratory stocks of a strain may contribute to differences in growth kinetics, final yield, and transcription $[10,40]$. In the present case, the commensal E. coli MG1655 lacks many of the genes associated with pathogenesis in S. Typhimurium with the cumulative result that adhesion in preparation for colonization is not E. coli MG1655's preferred response to LSMMG. Thus, the dramatically different response to LSMMG that was observed between E. coli MG1655 and S. Typhimurium was perhaps not unexpected. The key conclusion here is that even closely related species can respond to LSMMG in different ways. This is a frustrating outcome for those seeking to ascertain what the effect of exposure to low-shear or the space environment will be for microorganisms in general.

\section{Conclusion}

Since the evolution of bacteria has occurred in uniform gravity, it would seem unlikely that genes governing a direct response to variations in gravity would have evolved. With specific reference to the LSMMG environ- 


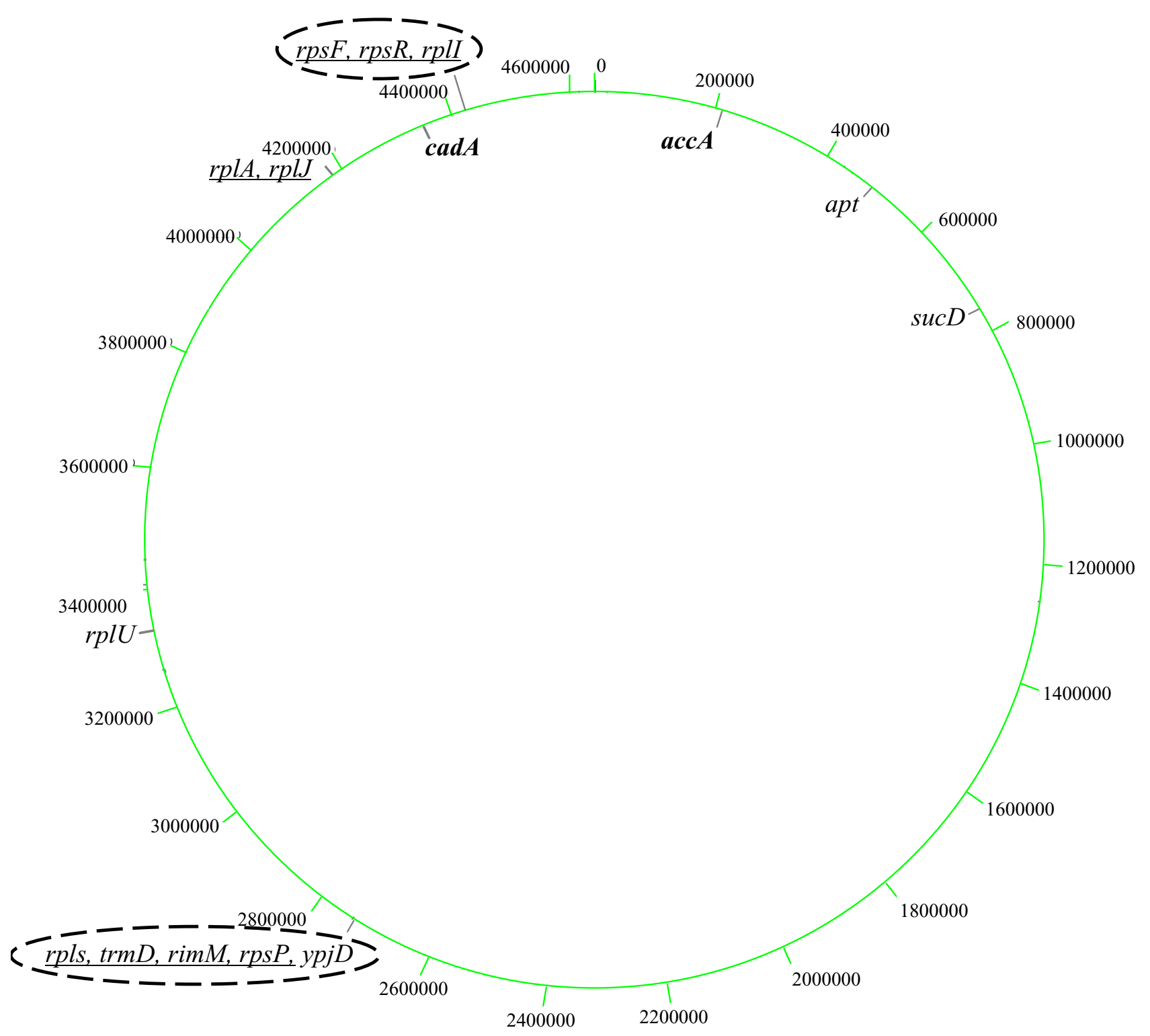

\section{Figure 2}

Schematic representation of the circular E. coli MG 655 chromosome with kilobase coordinates indicated. LSMMG up-regulated genes in rich LB medium are in bold and down-regulated genes are in regular case. In this figure, commas between gene names indicate gene proximity in the $E$. coli genome. Underlined genes are likely co-transcribed. The dashed ovals indicate gene clusters.

ment then, it would be anticipated that direct or indirect effects of low-shear such as alterations in the extracellular fluid environment due to reduced mixing are likely to be more important in the bacterial transcriptional response than a direct effect of the randomized gravity vector. If there is in fact an increase in cell motility, then the resulting shear forces created by this motility should be considered too. If a specific response to changes in the gravity 


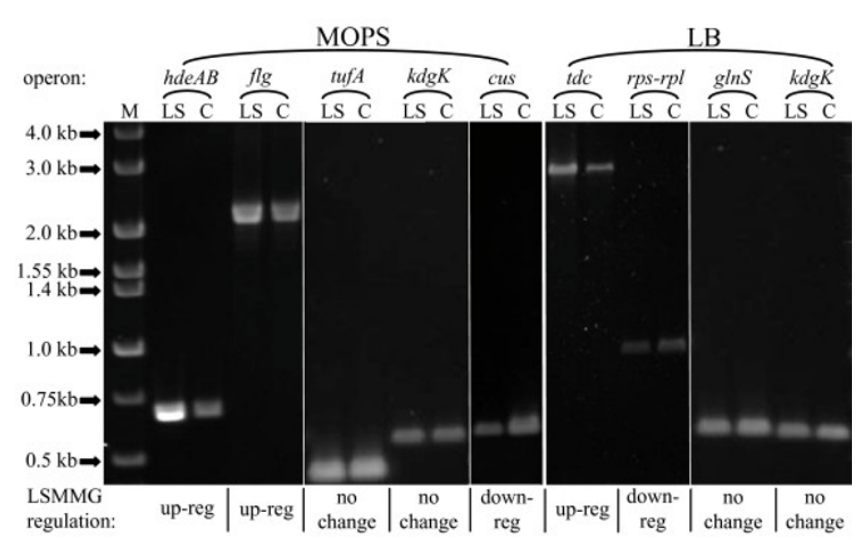

Figure 3

RT-PCR comparison of E. coli MGI655 LSMMG (LS) and control (C) samples. Template RNA was isolated from mid-logarithmic cells grown in MOPS (left panel) or LB (right panel) medium. LSMMG up- or down-regulation of each putative operon, determined by functional genomic analysis, is indicated below the gel image. Lanes: $\mathrm{M}$, Hi-Lo DNA markers (Minnesota Molecular, Inc); hdeAB; flgBCDE; cusCF; tdcDEFG; rpsF-priB-rpsR-rpll. See materials and methods for details.

vector were occurring, these would likely be seen regardless of growth condition. Based on the comparison of LSMMG regulated genes in rich and minimal medium, there does not appear to be such a generalized LSMMG response system or gene in E. coli MG1655. This conclusion is further supported by the absence of a strong correlation with the responses seen in $S$. Typhimurium.

Thus, the minimal media response to LSMMG seen here is more likely a response to conditions created by the loss of the gravity vector, e.g. low shear, than to gravity itself. A further test of this conclusion might be made by examining E. coli cultures growing in LSMMG environments under anaerobic conditions. If the change in a gene's expression is a direct response to gravity then it should respond in a similar manner regardless of aeration conditions.

\section{Methods \\ Culture conditions}

Wild type E. coli MG1655 (CGSC7740) was grown aerobically in the HARV bioreactors at $37^{\circ} \mathrm{C}$, in $50 \mathrm{ml}$ of minimal MOPS medium ( $\mathrm{pH}$ 7.4) developed for E. coli proteome studies [8] with $0.2 \%$ glucose as the sole source of carbon and energy or in Luria Broth [41]. This strain was selected because its genome is completely sequenced and well annotated. Cell growth was monitored spectrophotometrically at $600 \mathrm{~nm}$. To ensure culture comparability between growth vessels, a bulk culture was inoculated from a shaken overnight $3.0 \mathrm{ml}$ culture (medium matching experimental medium) to an initial OD600 of less than 0.0015 to ensure that cells experienced at least ten generations in the HARV's prior to reaching the mid-log phase of growth [42]. This inoculated bulk culture was aliquoted $(50 \mathrm{ml} /$ each) into two HARV vessels (Fig. 4A and 4B; Synthecon Inc., Houston, TX): the LSMMG environment was obtained by HARV rotation on a horizontal axis (Fig. 4C) and the control HARV vessel was rotated on a vertical axis (Fig. 4D). The HARV bioreactors were completely filled and rotated at $25 \mathrm{rpm}[4,5]$. Gas exchange occurs by perfusion through a permeable membrane and is sufficient to maintain an aerobic environment. Based on the shapes of the growth curves, an OD600 of 0.4 and 0.5 was selected as the mid-point of logarithmic growth for cell harvest in minimal and rich media, respectively. The time between medium inoculation and the samples reaching an OD600 $=0.1$ was chosen as the length of culture lag phase. An OD600 of 0.1, the sensitivity limit of the spectrophotometer, was selected as an indicator of the end of lag-phase and the beginning of exponential growth. Thirteen separate minimal MOPS and sixteen LB medium growth experiments were performed in this study.

\section{Medium composition analysis}

$1.0 \mathrm{ml}$ harvested culture was syringe filtered $(0.2 \mu \mathrm{m}$, Corning, NY) and the cleared medium was analyzed on a Ciba Corning 248 Blood Gas Analyzer (Bayer Diagnostics, Tarrytown, NY) for $\mathrm{pH}, \mathrm{CO}_{2}(\mathrm{mmHg}), \& \mathrm{O}_{2}(\mathrm{mmHg})$. Glucose concentration $(\mathrm{mg} / \mathrm{dl})$ was measured with an Eppendorf Glucose Analyzer (Westbury, NY).

\section{Post-LSMMG antibiotic and stress resistance}

Antibiotics \& stress stocks were diluted into $1 \times$ phosphate buffered saline ( $\mathrm{pH}$ 7.4). Antibiotic concentrations employed were: $9 \mu \mathrm{g} / \mathrm{ml}$ ampicillin, $1.25 \mu \mathrm{g} / \mathrm{ml}$ kanamycin, $0.1 \mu \mathrm{g} / \mathrm{ml}$ colistin (polymyxin E), $40 \mu \mathrm{g} / \mathrm{ml}$ chloramphenicol, and $20 \mu \mathrm{g} / \mathrm{ml}$ rifampicin (Sigma-Aldrich, St. Louis, MO). These antibiotics were chosen based on their different cellular effects: cell wall disruption, translation inhibition (binding 30S ribosomal subunit), cytoplasmic membrane disruption, translation inhibition (binding 50 S ribosomal subunit) and transcription inhibition, respectively. The bacterial stress conditions included acidic (0.05 $\mathrm{M}$ citrate buffer, $\mathrm{pH} 4.25$ ) and basic conditions (saline, $\mathrm{pH} 10.0)$, oxidative stress $\left(0.0015 \% \mathrm{H}_{2} \mathrm{O}_{2}\right)$, osmotic stress (450 mM NaCl and $850 \mathrm{mM}$ sucrose), alcohol stress $(9.5 \% \mathrm{EtOH})$ and heat shock $\left(50^{\circ} \mathrm{C}\right)$ (chemicals from Sigma-Aldrich). Mid-log phase HARV cultures were diluted to $10^{-2}$ in $1.0 \mathrm{ml}$ of the desired stress solution or antibiotic and statically incubated for 1 hour at $37^{\circ} \mathrm{C}$ in sealed $1.5 \mathrm{ml}$ Eppendorf tubes except for the heat shock sample incubated at $50^{\circ} \mathrm{C}$. After stress incubation, stressed cultures were further diluted in saline and triplicate plated to $10^{-6}$ on LB agar plates that were incubated overnight at $37^{\circ} \mathrm{C}$. Triplicate colony plate counts were 
Table 4: E. coli MGI655 gene expression ratios compared to homologous gene expression ratios of S. Typhimurium [5I].

\begin{tabular}{|c|c|c|c|c|c|}
\hline \multicolumn{3}{|c|}{ E. coli MOPS LSMMG up-regulated } & \multicolumn{3}{|c|}{ homologous Salmonella genes } \\
\hline gene & $\underline{\mathbf{b} \#}$ & ratio & gene & STM ID\# & ratio \\
\hline flgB & b $\overline{1073}$ & $\overline{2.08}$ & $f \lg B$ & $\overrightarrow{\text { STMII74 }}$ & $<2$ \\
\hline flgD & b 1075 & 1.96 & flg $D$ & STMII76 & $<2$ \\
\hline flge & b 1076 & 2.40 & flgE & STMII 77 & $<2$ \\
\hline ydfD & b/576 & 2.64 & not present & & \\
\hline fliZ & b|92I & 2.22 & fliz & STMI955 & $<2$ \\
\hline $\operatorname{dct} R$ & b3507 & 2.58 & not present & & \\
\hline hdeB & b3509 & 6.25 & slyA & STMI444 & $<2$ \\
\hline hdeA & b35 I0 & 4.41 & slyA & STMI444 & $<2$ \\
\hline hdeD & b35 I l & 3.51 & not present & & \\
\hline gadE & b35 I 2 & 2.56 & not present & & \\
\hline
\end{tabular}

E. coli MOPS LSMMG down-regulated

homologous Salmonella genes

\begin{tabular}{|c|c|c|c|c|c|}
\hline gene & b\# & ratio & gene & STM ID\# & ratio \\
\hline copA & b0484 & -2.37 & copA & STM0498 & $<2$ \\
\hline ybch & b0567 & -3.25 & not present & & \\
\hline cusC & b0572 & -2.74 & STM0350 & STM0350 & $<2$ \\
\hline cusF & b0573 & -4.13 & not present & & \\
\hline cusA & b0575 & -3.33 & STM0350 & STM0350 & $<2$ \\
\hline uspG & b0607 & -2.58 & $y b d Q$ & STM06I4 & $<2$ \\
\hline yfiA & b2597 & -2.84 & yfia & STM2665 & $<2$ \\
\hline$a \subset c B$ & b3255 & -2.67 & $a c c B$ & STM3379 & $<2$ \\
\hline$c p \times P$ & b3913 & -2.85 & $c p x P$ & STM4060 & $<2$ \\
\hline
\end{tabular}

E. coli LB LSMMG up-regulated

homologous Salmonella genes

\begin{tabular}{lcclcl}
\hline gene & b\# & ratio & gene & STM ID\# & $\frac{\text { ratio }}{\text { accA }}$ \\
b0185 & 1.97 & STM0232 & $<2$
\end{tabular}

\section{E. coli LB LSMMG down-regulated}

\begin{tabular}{|c|c|c|c|c|c|}
\hline gene & b\# & ratio & gene & STM ID\# & ratio \\
\hline sucD & b0729 & -1.77 & sucD & STM0739 & -3.33 \\
\hline $\operatorname{rim} M$ & b2608 & -2.07 & $\operatorname{rim} M$ & STM2675 & $<2$ \\
\hline$r p s P$ & b2609 & -2.48 & $r p s P$ & STM2676 & $<2$ \\
\hline rplA & b3984 & -2.03 & $r p / A$ & STM4I50 & $<2$ \\
\hline rplJ & b3985 & -2.49 & rpll & STM4I5I & $<2$ \\
\hline rpsF & b4200 & -2.23 & $r p s F$ & STM439I & $<2$ \\
\hline rpsR & b4202 & -2.41 & $r p s R$ & STM4393 & $<2$ \\
\hline rpll & b4203 & -2.06 & rpll & STM4394 & $<2$ \\
\hline
\end{tabular}

averaged and stress survival reported as a percentage of untreated, incubated control culture survival (control cultures diluted to $10^{-2}$ in saline with subsequent incubation, dilutions, and plating as in stressed samples). Antibiotic and stress concentrations were optimized for approximately 50\% culture survival from mid-log $250 \mathrm{rpm}$ shaken E. coli cultures. Both time 0 and time $60 \mathrm{~min}$. control platings were performed.

\section{RNA isolation and probe synthesis}

Cells for RNA isolation were harvested from the mid-logarithmic phase of growth by removing $5.0 \mathrm{ml}$ of culture and mixing with $5.0 \mathrm{ml}$ of ice-cold RNA-Later (Ambion,
Austin, TX). Cells were pelleted from this mixture by centrifugation and RNA was isolated and purified with $\mathrm{RNe}$ asy Mini Kit columns (Qiagen, Valencia, CA). Genomic DNA was removed by DNaseI (Ambion) treatment, with subsequent RNA re-purification with an RNeasy column [42]. RNA samples were quantified by $260 \mathrm{~nm}$ absorbance. Hybridization probes were generated as described in Tucker et al. [42]. Radiolabel incorporation was determined by scintillation count comparison prior and subsequent to removal of unincorporated nucleotide by G-50 Sephadex column filtration [41]. This procedure routinely supplied cDNA samples with 70-90\% label incorporation [42]. 
Table 5: S. Typhimurium gene expression ratios [5I] compared to the homologous E. coli MG 1655 genes.

\begin{tabular}{|c|c|c|c|c|c|c|}
\hline \multicolumn{3}{|c|}{ Salmonella LB LSMMG up-regulated } & \multicolumn{4}{|c|}{ homologous $E$. coli gene expression } \\
\hline gene & STM ID\# & $\underline{\text { ratio }}$ & gene & $\underline{\mathbf{b} \#}$ & $\underline{\text { LB ratio }}$ & MOPS ratio \\
\hline leuC & STMOIII & 8.33 & leuC & b0072 & 1.17 & 1.30 \\
\hline yaiV & STM0374 & 8.33 & yaiV & b0375 & 1.33 & 1.18 \\
\hline thiJ & STM0433 & 8.33 & thil & b0424 & 1.06 & -1.06 \\
\hline rstB & STMI47I & 10 & $r s t B$ & bl609 & -1.06 & 1.00 \\
\hline cysl & STM2947 & 8.33 & cysl & b2763 & 1.26 & 1.05 \\
\hline pgk & STM3039 & 10 & pgk & b2926 & -1.29 & -1.17 \\
\hline yhgN & STM3540 & 8.75 & yhgN & b3434 & -1.07 & -1.04 \\
\hline dppA & STM3630 & 8.33 & $d p p A$ & b3544 & -1.03 & 1.28 \\
\hline yjdC & STM4322 & 8.33 & $y j d C$ & b4 135 & -1.03 & 1.03 \\
\hline STM4545 & STM4545 & 8.75 & $y j j B$ & b4363 & 1.04 & -1.03 \\
\hline \multicolumn{3}{|c|}{ Salmonella LB down-regulated } & \multicolumn{4}{|c|}{ homologous E. coli gene expression } \\
\hline$n f n B$ & STM0578 & -3.13 & $n f n B$ & b0578 & -1.28 & -1.07 \\
\hline $\operatorname{ahpC}$ & STM0608 & -5.26 & $\operatorname{ahpC}$ & b0605 & -1.18 & -1.09 \\
\hline sucD & STM0739 & -3.33 & sucD & b0729 & -1.77 & -1.02 \\
\hline$d p s$ & STM083 I & -3.33 & $d p s$ & b0812 & 1.35 & -1.12 \\
\hline cybB & STMI639 & -3.45 & $c y b B$ & bl418 & -1.14 & -1.02 \\
\hline fruK & STM2205 & -5.88 & fruK & b2168 & 1.07 & -1.15 \\
\hline yfiC & STM2624 & -4.55 & yfiC & b2575 & -1.13 & 1.21 \\
\hline rplo & STM342I & -3.57 & $r p l O$ & b330l & -1.21 & 1.02 \\
\hline rpoc & STM4I54 & -5.56 & rpoc & b3988 & -1.45 & 1.16 \\
\hline yjeP & STM4347 & -3.23 & yjeP & b4159 & 1.13 & -1.05 \\
\hline
\end{tabular}

Positive gene expression ratios indicate LSMMG up-regulation and negative ratios indicate down-regulation.

\section{Array hybridization}

Matched pairs of PCR-product DNA macroarrays (Panorama E. coli Gene Arrays; Sigma-Genosys, Houston, TX), which have been employed with considerable success by a number of research groups $[7,17,43-47]$, were rinsed, pre-hybridized $\left(65^{\circ} \mathrm{C}\right.$ for $\left.4 \mathrm{hr}\right)$, hybridized $\left(65^{\circ} \mathrm{C}\right.$ for $16-$ $18 \mathrm{hr}$ ), washed, and wrapped in Saran Wrap as described in Tucker et al. [42]. The arrays were then exposed to Fuji BAS-IP MS Phosphor Screens (FUJIFILM Medical Systems USA Inc., Stafford, TX) for 24 hrs. Exposed phosphor screen images were visualized at a pixel density of 50 microns $\left(40,000\right.$ dots $\left./ \mathrm{cm}^{2}\right)$ with a Storm 860 PhosphorImager (Molecular Dynamics, Sunnyvale, CA). Arrays were stripped of hybridized probe by boiling inverted arrays in a microwave $\left(100^{\circ} \mathrm{C}\right)$ in $200 \mathrm{ml}$ of stripping solution (10 mM Tris $\mathrm{pH} 7.5,1 \mathrm{mM}$ EDTA, and $1 \%$ SDS) for 20 minutes. The array membranes used in these experiments were consecutively hybridized, stripped, and re-hybridized up to seven times (Table 6). Array comparability was maintained, with only one of the biological RNA sample sets having a correlation coefficient less than 0.964 (LB RNA 2; 0.929), indicating minimal PCR probe spot degradation on the arrays even after multiple stripping and hybridizations (Table 6).

\section{Image acquisition and data analysis}

Hybridized membrane phosphorimages were imported into image analysis software developed in the UH Bioin- formatics Laboratory to obtain the raw spot intensity data [14]. This data was transferred to a series of Microsoft Excel DNA array analysis macro's described in detail in Conway et al. [38] and available from the University of Oklahoma Microarray and Bioinformatics Core Facility [49]. These macros normalized the image data by expressing each spot as a percentage of the sum of intensities of all spots on the array image and determined the standard deviation of the log ratios of gene expression and Student t-test p-values of each gene from two technical replicates (repeated hybridization of the same RNA sample onto both arrays of an array pair) for the two RNA sample conditions (LSMMG and control) [38]. Significant changes in gene expression were identified based on three previously documented criteria: 1) an overall p-value of $<0.05$ which implies a $95 \%$ probability that a change in expression between strains or media was significant [43]; 2) a log ratio of gene expression which differed from the mean of the $\log$ ratios by $>3.0$ standard deviations giving a $99.9 \%$ confidence in gene expression [42]; and 3) similar gene expression in all three biological replicates. In addition, a fold change analysis was conducted as described in the supplementary information [additional files 4, 5, 6] Combining statistical methods increases the probability that genes remaining after statistical analysis are in fact changing significantly under the condition of LSMMG $[11,42,46]$. 
A.

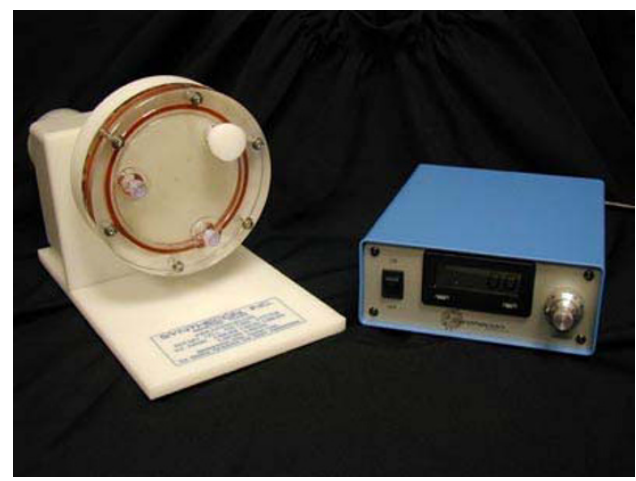

C.

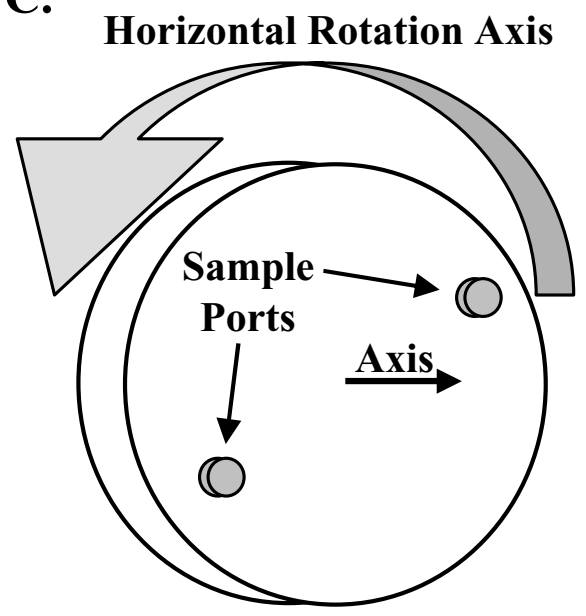

LSMMG
B.

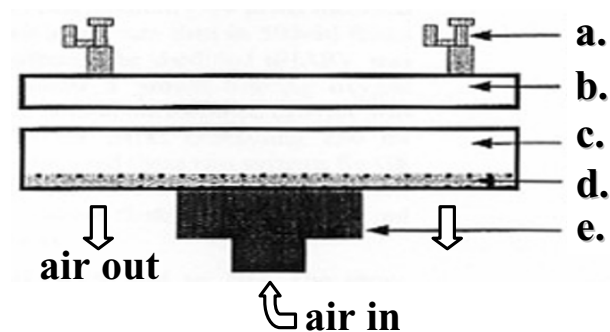

D.

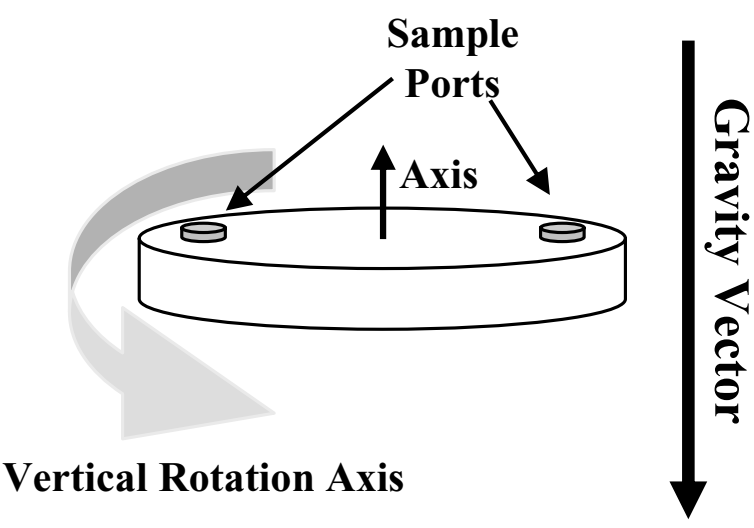

Control

Figure 4

(A) Image of the High Aspect Rotating Vessel (HARV) attached to the rotating/aerating platform and controller (reproduced with permission from Synthecon Inc., Houston, TX). (B) Diagram of the HARV bioreactor vessel with samples ports (a.), front plate (b), $50 \mathrm{ml}$ culture chamber (c), gas permeable membrane (d), and rotator hub base (e) indicated. (C) Low-shear modeled microgravity and (D) control orientations of HARV bioreactors employed for culture growth in these experiments. All cultures were grown at $37^{\circ} \mathrm{C}$ and HARV rotation was $25 \mathrm{rpm}$.

The data sets used for statistical analysis in this study included three MOPS biological RNA replicates and three LB biological RNA replicates hybridized to 4 membrane pairs with at least two technical replicates of each sample condition (Table 6). Raw image data and analysis results are provided as supplementary materials [additional files $7,8,9,10,11,12]$ and also are available at [14]. The correlation coefficients between LSMMG or control RNA sets isolated from the same media indicated acceptable comparability between the media dependent biological replicates (Table 7). The decreased comparability of LSMMG and control samples between LB and MOPS medium was apparently related to the differences in nutrients and the growth rates of these cultures (Table 7 ).
In order to estimate the number of genes which might pass the statistical criteria by chance (the false positive rate), a permutation test of the $\mathrm{p}=0.05$ criterion was undertaken as described in detail in the supplementary materials [additional file 13]. For every gene, we randomly shuffled the ratios (ri) between the control and experimental groups and then the mean and standard deviation of ratios for all groups of spots (including duplicates) that corresponded to the same gene. As above, the change in expression of a gene is considered to be significant if the mean value of the control versus experiment ratio exceeds two standard deviations $(p=0,05)$. The same analysis was applied to the randomized dataset. The detailed permutation results are available at the project 
Table 6: Membrane array hybridization and sample repetitions employed and biological RNA set correlation coefficients.

\begin{tabular}{|c|c|c|c|c|}
\hline Array Hyb. & $\begin{array}{l}\text { Sample Hybrid. } \\
\text { to array A5013A }\end{array}$ & $\begin{array}{l}\text { Sample Hybrid. } \\
\text { to array A50 I3B }\end{array}$ & $\begin{array}{l}\text { From RNA } \\
\text { Sample Sets }\end{array}$ & $\begin{array}{l}\text { Correlation } \\
\text { Coefficient }\end{array}$ \\
\hline I & MOPS LSMMG & MOPS control & MOPS set I & \\
\hline 2 & MOPS control & MOPS LSMMG & MOPS set I & 0.988 \\
\hline 6 & MOPS LSMMG & MOPS control & MOPS set 2 & \\
\hline \multirow[t]{2}{*}{7} & MOPS control & MOPS LSMMG & MOPS set 2 & 0.984 \\
\hline & to array $\mathrm{A} 50 \mathrm{I} \mid \mathrm{A}$ & to array A50 I IB & & \\
\hline I & & & MOPS control & MOPS set 3 \\
\hline 2 & MOPS LSMMG & & & MOPS set 3 \\
\hline 3 & MOPS control & MOPS LSMMG & MOPS set 3 & 0.965 \\
\hline 5 & LB LSMMG & LB control & LB set I & \\
\hline \multirow[t]{2}{*}{6} & LB control & LB LSMMG & LB set I & 0.987 \\
\hline & to array AT030A & to array AT030B & & \\
\hline 2 & LB control & LB LSMMG & LB set 2 & \\
\hline \multirow[t]{2}{*}{5} & LB LSMMG & LB control & LB set 2 & 0.929 \\
\hline & to array AT032A & to array AT032B & & \\
\hline I & LB LSMMG & LB control & LB set 3 & \\
\hline 2 & LB control & LB LSMMG & LB set 3 & 0.965 \\
\hline
\end{tabular}

web site [14]. The average number of genes which appear to be significant by chance was less than one (0.86) in the LB experiments and less than two (1.67) in the MOPS experiments. Given these low values of expected false positives and the use of two additional criteria, it is concluded that the observed differences between the experimental and control groups are real and can not be explained by random events.

Online databases were used for gene nomenclature, gene location and orientation, putative co-transcription, product function, and presence in $S$. Typhimurium. Colibiri [50] was used to determine individual gene locations and orientations in the E. coli genome as well as possible cotranscription with other expressed genes. EcoCyc (Institute for Genomic Research, University of California; San Diego, CA [51]) and EcoSearch (University of Miami School of Medicine; Miami, FL [52]) were used in determining gene names/synonyms and gene product function. The coliBase website [53] was used to identify genes significantly expressed in this study that are present or have an orthologue in $S$. Typhimurium.

\section{RT-PCR analysis}

For each sample, 500 pg of DNAse-treated mid-log isolated RNA used in the macroarray analysis (described above) served as template for reverse transcriptase PCR (RT-PCR) analysis. Thirty PCR cycles were used during cDNA amplification. RT-PCR primers (20-22 mers) were designed to produce PCR fragments of predetermined size if template mRNA for the gene or operons was present in the sample. Transcription of the MOPS LSMMG up-regulated operons flgBCDE and $h d e A B$ and the down-regulated cusCF were evaluated with primers $f l g B>$ flgE (5'AGAACTGCAATACCGTATTCC-3') and flgB <flgE (5'GAAGCTCAGACTAAACGTGG-3') producing a 2094 bp product; $h d e A$ > hdeB (5'-TCAACTCCTGGACCTGTGAAG$\left.3^{\prime}\right)$ and $h d e A<h d e B\left(5^{\prime}\right.$-AATTCGGCAAGTCATTAGATGC3'), 674 bp product; and cusC $>$ cusA (5'-AGTAAGTTATCTGGAAGTGCTG-3') and cusC <cusA (5'-ACCAGTGCATATTCATAGATCC-3'), 614 bp product. Evaluation of LB

Table 7: Correlation coefficients of LSMMG and control RNA's between the biological RNA sets.

\begin{tabular}{lcc}
\hline $\begin{array}{l}\text { RNA sets } \\
\text { Compared }\end{array}$ & LSMMG & Correlation Coefficients \\
MOPS RNA sets I \& 2 & 0.907 & 0.87 \\
MOPS RNA sets I \& 3 & 0.914 & 0.927 \\
MOPS RNA sets 2 \& 3 & 0.932 & 0.86 \\
LB RNA sets I \& 2 & 0.935 & 0.888 \\
LB RNA sets I \& 3 & 0.846 & 0.847 \\
LB RNA sets 2 \& 3 & 0.905 & 0.943 \\
LB set I \& MOPS set I & & 0.676
\end{tabular}


LSMMG up-regulated $t d c D E F G$ and down-regulated $r p s F-$ $r p l I$ was performed with primers $t d c D>t d c G$ (5'TCAAGCTTAATTCGTCGTCTG-3') and $t d c D<t d c G$ (5'GTTAATAAGCCGCTACTTTCCA-3'), 3139 bp product; and $r p s F>r p l I$ (5'-TCTGATGAATGTTGAAGCTCC-3') and $r p s F<r p l I$ (5'-TTTAGACGCGATGGTAACAG-3'), 1060 bp product. RT-PCR was performed with the Qiagen OneStep RT-PCR kit and RT-PCR products were visualized on $0.8 \%$ Tris-borate-EDTA-EtBr-stained agarose gels. RT-PCR fragment sizes were determined by comparison to $\mathrm{Kb}$ DNA ladder (Stratagene, Cedar Creek, TX) for subsequent comparison to predicted fragment sizes. Negative control RT-PCR reactions were used to verify decreased transcription of genes and operons in the paired RNA samples (control RNA for LSMMG up-regulated genes and LSMMG RNA for LSMMG down-regulated genes) and to verify the absence of contaminating DNA that would serve as a template for artifactual RT-PCR products.

\section{Abbreviations}

LSMMG: low-shear modeled microgravity

HARV: high aspect rotating vessel

LB: luria broth (rich medium)

MOPS: Neidhardt's MOPS-Based Defined Media

RT-PCR: reverse transcription - polymerase chain reaction

\section{Authors' contributions}

The overall experimental design was conceived and planned by DLT, GEF, RCW and DLP. All experimental work was carried out by DLT in collaboration with CMO. CMO and DLP participated in the detailed design and trouble shooting of the HARV experiments. DLT conducted the primary data processing and statistical analysis. The permutation test of the results was designed by YF with assistance from DLT, SH, and GEF and conducted and documented by SH. DLT wrote the manuscript which was edited and revised by RCW, YF, and GEF. All authors read and approved the final manuscript.

\section{Additional material}

\section{Additional file 1}

$L B$ growth curves. OD600 vs time in LB media

Click here for file

[http://www.biomedcentral.com/content/supplementary/1471-

2180-7-15-S1.xls]

\section{Additional file 2}

MOPS growth curve. OD600 vs time in MOPS media.

Click here for file

[http://www.biomedcentral.com/content/supplementary/1471-

2180-7-15-S2.xls]

\section{Additional file 3}

Stress test results. Plate count survival data.

Click here for file

[http://www.biomedcentral.com/content/supplementary/1471-

2180-7-15-S3.xls]

\section{Additional file 4}

Fold change analysis. Describes how Fold-change differences in gene expression between the compared conditions (LSMMG and $1 \times \mathrm{g}$ control) were calculated.

Click here for file

[http://www.biomedcentral.com/content/supplementary/1471-

2180-7-15-S4.doc]

\section{Additional file 5}

Detailed results of fold change analysis in LB media. Gene by gene results of fold change analysis

Click here for file

[http://www.biomedcentral.com/content/supplementary/14712180-7-15-S5.xls]

\section{Additional file 6}

Detailed results of fold change analysis in MOPS media. Gene by gene results of fold change analysis

Click here for file

[http://www.biomedcentral.com/content/supplementary/14712180-7-15-S6.xls]

\section{Additional file 7}

$L B$ replicate 1. Detailed data and analysis for $L B$ replicate 1 Click here for file [http://www.biomedcentral.com/content/supplementary/14712180-7-15-S7.xls]

\section{Additional file 8}

$L B$ replicate 2. Detailed data and analysis for $L B$ replicate 2 Click here for file [http://www.biomedcentral.com/content/supplementary/14712180-7-15-S8.xls]

\section{Additional file 9}

$L B$ replicate 3. Detailed data and analysis for $L B$ replicate 3 Click here for file

[http://www.biomedcentral.com/content/supplementary/14712180-7-15-S9.xls]

\section{Additional file 10}

MOPS replicate 1. Detailed data and analysis for MOPS replicate 1 Click here for file

[http://www.biomedcentral.com/content/supplementary/14712180-7-15-S10.xls]

\section{Additional file 11}

MOPS replicate 2. Detailed data and analysis for MOPS replicate 2 Click here for file

[http://www.biomedcentral.com/content/supplementary/14712180-7-15-S11.xls] 


\section{Additional file 12}

MOPS replicate 3. Detailed data and analysis for MOPS replicate 3 Click here for file

[http://www.biomedcentral.com/content/supplementary/14712180-7-15-S12.xls]

\section{Additional file 13}

Permutation test. Detailed description of permutation test Click here for file

[http://www.biomedcentral.com/content/supplementary/14712180-7-15-S13.doc]

\section{Acknowledgements}

This research was funded in part by grants from the Institute of Space Systems Operations to GEF and DLT, the National Aeronautics and Space Administration Exploration Systems Mission Directorate (NNJ04HF43G) and National Space Biomedical Research Institute (cooperative agreement NCC-9-58) to GEF and RCW. We like to thank Dr. Lawrence A. Donehower for allowing access to a Molecular Dynamics Storm 860 Phosphorimager in the Blot Analysis Core Laboratory at the Baylor College of Medicine.

\section{References}

I. Stock UA, Vacanti JP: Cardiovascular physiology during fetal development and implications for tissue engineering. Tissue Eng 200I, 7:1-7.

2. Nickerson CA, Ott CM, Wilson JW, Ramamurthy R, Pierson DL: Microbial responses to microgravity and other low-shear environments. Microbiol Mol Biol Rev 2004, 68(2):345-36I.

3. Klaus D: Clinostats and bioreactors. Gravitational and Space Biology Bulletin 200I, I4(2):55-64

4. Nickerson CA, Ott CM, Mister SJ, Morrow BJ, Burns-Keliher L, Pierson DL: Microgravity as a novel environmental signal affecting Salmonella enterica serovar Typhimurium virulence. Infection and Immunity 2000, 68:3147-3152.

5. Wilson JW, Ramamurthy R, Porwollik S, McClelland M, Hammond T, Allen P, Ott CM, Pierson DL, Nickerson CA: Microarray analysis identifies Salmonella genes belonging to the low-shear modeled microgravity regulon. Proc Natl Acad Sci U S A 2002 99(2I): I3807-|38|2.

6. Blattner FR, Plunkett G, Bloch CA, Perna NT, Burland V, Riley M, Collando-Vides J, Glasner JD, Rode CK, Mayhew GF, Gregor J, Davis NW, Kirkpatrick HA, Goeden MA, Rose DJ, Mau B, Shao Y: The complete genome sequence of Escherichia coli K-I 2. Science |997, 277(533 |):|453-|474.

7. Mori H: From the sequence to cell modelling: comprehensive functional genomics in Escherichia coli. J Biochem Mol Biol 2004 37( I):83-92.

8. Neidhardt FC, Bloch PL, Smith DF: Culture medium for enterobacteria. I Bact 1974, I | 9:736-747.

9. McClelland M, Florea L, Sanderson K, Clifton SW, Parkhill J, Churcher C, Dougan G, Wilson RK, Miller W: Comparison of the Escherichia coli K-12 genome with sampled genomes of a Klebsiella pneumoniae and three Salmonella enterica serovars, Typhimurium, Typhi, and Paratyphi. Nucleic Acids Res 2000, 28(24):4974-4986.

10. Wilson JW, Ott CM, Ramamurthy R, Porwollik S, McClelland M, Pierson DL, Nickerson CA: Low-Shear modeled microgravity alters the Salmonella enterica serovar typhimurium stress response in an RpoS-independent manner. Appl Environ Microbiol 2002, 68(I I):5408-54 I6.

II. Conway T, Schoolnik GK: Microarray expression profiling: capturing a genome wide portrait of the transcriptome. Molec Microbiol 2003, 47(4):879-889.

12. Alexeeva S, Hellingwerf KJ, de Mattos MJT: Quantitative assessment of oxygen availability: perceived aerobiosis and its effect on flux distribution in the respiratory chain of Escherichia coli. J Bact 2002, I 84(5): | 402-| 406.

13. Lynch SV, Brodie EL, Matin A: Role and regulation of ss in general resistance conferred by low-shear simulated microgravity in Escherichia coli. J Bacteriol 2004, I 86(24):8207-82 I 2 .

14. Supplementary material for the characterization of Escherichia coli MGI655 grown in a low-shear modeled microgravity environment [http://prion.bchs.uh.edu/LSMMG/]

15. Ma Z, Richard H, Tucker DL, Conway T, Foster JW: Genes of the GadX-GadW regulon in Escherichia coli. J Bact 2003 , I 85(10):3190-3201.

16. Gajiwala KS, Burley SK: HDEA, a periplasmic protein that supports acid resistance in pathogenic enteric bacteria. J Molec Biol 2000, 295:605-6I2.

17. Tucker DL, Tucker N, Ma Z, Foster JW, Miranda RL, Cohen PS, Conway T: Genes of the GadX-GadW regulon in Escherichia coli. J Bact 2003, I 85( I 0):3190-3201.

18. Soutourina OA, Bertin PN: Regulation cascade of flagellar expression in Gram-negative bacteria. FEMS Microbiol Reviews 2003, 27:505-523.

19. Sagi Y, Khan S, eisenbach M: Binding of the chemotaxis response regulator CheY to the isolated, intact switch complex of the bacterial flagellar motor. I Biol Chem 2003. 278( I I ):25867-2587I.

20. Serres MH, Goswami S, Riley M: GenProtEC: an updated and improved analysis of functions of Escherichia coli K-I 2 proteins. Nucleic Acids Res 2004, 32(I):D300-302.

21. Rensing C, Grass G: Escherichia coli mechanisms of copper homeostasis in a changing environment. FEMS Microbiol Reviews 2003, 27:197-213.

22. Danese PN, Silhavy TJ: CpxP, a stress-combative member of the Cpx regulon. J Bact 1998, I 80(4):83 I-839.

23. Shimohata N, Chiba S, Saikawa N, Ito K, Akiyama Y: The Cpx stress response system of Escherichia coli senses plasma membrane proteins and contols HtpX, a membrane protease with a cytosolic active site. Genes to Cells 2002, 7:653-662.

24. Rak A, Kalinin A, Shcherbakov D, Bayer P: Solution structure of the ribosome-associated cold shock response protein $Y$ fia of Escherichia coli. Biochem Biophys Res Commun 2002, 299(5):7|0-7|4.

25. Leonhartsberger S, Huber A, Lottspeich F, Bock A: The hydH/G genes from Escherichia coli code for a zinc and lead responsive two-component regulatory system. I Molec Biol 200I, 307(I):93-105.

26. Nishino K, Yamaguchi A: Analysis of a complete library of putative drug transporter genes in Escherichia coli. J Bact 200I, I 83(20):5803-58|2.

27. Choi-Rhee E, Cronan JE: The biotin carboxylase-biotin carboxyl carrier protein complex of Escherichia coli acetyl-Co carboxylase. J Biol Chem 2003, 278(33):30806-308I2.

28. Raivio TL, Laird MW, Joly JC, Silhavy TJ: Tethering of CpxP to the inner membrane prevents spheroplast induction of the $\mathbf{C p x}$ envelope stress response. Molec Microbiol 2000 , 37(5): I | 86-I I97.

29. Hung DL, Raivio TL, Jones CH, Silhavy TJ, Hultgren SJ: Cpx signaling pathway monitors biogenesis and affects assembly and expression of P pili. EMBO Journal 200I, 20(7): I508-I5I8.

30. DiGiuseppe PA, Silhavy TJ: Signal detection and target gene induction by the CpxRA two-component system. J Bact 2003, I 85(8):2432-2440

31. Davis MS, Cronon J J. E.: Inhibition of Escherichia coli acetyl coenzyme A carboxylase by acyl-acyl carrier protein. J Bact 200I, I83(4): |499-I503.

32. Keener I Nomura $M$ : Regulation of ribosome synthesis. In Escherichia coli and Salmonella Cellular and Molecular Biology Volume I. 2nd edition. Edited by: Neidhardt FC. Washington, D.C. , ASM Press; 1996:Chpt. 90.

33. Lovgren JM, Bylund GO, Srivastava MK, Lundberg LA, Persson OP, Wingsle G, Wikstrom PM: The PRC-barrel domain of the ribosome maturation protein RimM mediates binding to ribosomal protein S19 in the 30 S ribosomal subunits. RNA 2004, I O(I I): I798-1812.

34. Cunningham L, Guest JR: Transcription and transcript processing in the sdhCDAB-subABCD operon of Escherichia coli. Microbiology 1998, I44(8):2 I |3-2 I 23. 
35. Urbonavicius J, Qian Q, Durand JM, Hagervall TG, Bjork GR: Improvement of reading frame maintenance is a common function for several tRNA modifications. EMBO journal 200I, 20:4863-4873.

36. Nickerson CA, Ott CM: $\mathbf{A}$ new dimension in modeling infectious disease. ASM News 2004, 70(4):169-175.

37. Todd $\mathrm{P}, \mathrm{K}$ laus DM: Theories and models on the biology of cells in space. Adv Space Res 1996, 17(6/7):3-10.

38. Conway T, Kraus B, Tucker DL, Smalley DJ, Dorman AF, McKibben $L$ : DNA array analysis in a Microsoft Windows environment. Biotechniques 2002, 32(I): I10-119.

39. Soupene E, van Heeswiik WC, Plumbridge J, Stewart V, Bertenthal D, Lee H, Prasad G, Paliy O, Charernnoppakul P, Kustu S: Physiological studies of Escherichia coli strain MG 1655: growth defects and apparent cross-regulation of gene expression. J Bact 2003 , 185(18):561 I-5626

40. Fang A, Pierson DL, Koenig DW, Mishra SK, Demain AL: Effect of simulated microgravity and shear stress on microcin BI7 production by Escherichia coli and on its excretion into the medium. Appl Environ Microbiol 1997, 63( I 0):4090-4092

41. Sambrook J, Fritsch EF, Maniatis T: . In Molecular Cloning A Laboratory Manual 2nd Edition Volume I-3. Cold Spring Harbor, Cold Spring Harbor Laboratory; 1989.

42. Tucker DL, Tucker N, Conway T: Gene expression profiling of the $\mathrm{pH}$ response in Escherichia coli. J Bact 2002, | 84(23):655I-6558.

43. Arfin F, Long AD, Ito ET, Tolleri L, Riehle MM, Paegle ES, Hatfield GW: Global gene expression profiling in Escherichia coli KI2 The effects of integration host factor. J Biol Chem 2000, 275:29672-29684.

44. Arnold CN, McElhanon J, Lee A, Leonhart R, Siegle DA: Global analysis of Escherichia coli gene expression during the acetateinduced acid tolerance response. I Bacteriol 200I, 183:2178-2186

45. Barbosa TM, Levy SB: Differential expression of over 60 chromosomal genes in Escherichia coli by constitutive expression of MarA. J Bacteriol 2000, I 82:3467-3474.

46. Richmond CS, Glasner JD, Mau R, Jin H, Blattner FR: Genome-wide expression profiling in Escherichia coli K-12. Nucleic Acids Res 1999, 27:382।-3835.

47. Tao H, Bausch C, Richmond C, Blattner FR, Conway T: Functional genomics: expression analysis of Escherichia coli growing on minimal and rich media. J Bact I999, I 8 I (20):6425-6440.

48. Shi L, Li TB, Tucker DL, Karouia F, Fox GE, Willson RC, Fofanov Y: A pair-wise correlation analysis applied to gene expression data from two E. coli strains: Houston, TX. Houston Society for Engineering in Medicine \& Biology; 2003:73.

49. OU Bioinformatics Core Facility [http://www.ou.edu/microar ray/]

50. Colibri World-Wide Web Server [http://genolist.pasteur.fr/ Colibri/genome.cgi]

5I. EcoCyc: Encyclopedia of Escherichia coli K-I2 Genes and Metabolism [http://ecocyc.org/]

52. EcoGene [http://bmb.med.miami.edu/]

53. Chaudhuri RR, Khan AM, Pallen MJ: coliBASE: an online database for Escherichia coli, Shigella and Salmonella comparative genomics. Nucleic Acids Res 2004, 32(Database issue):D296-D299.
Publish with Bio Med Central and every scientist can read your work free of charge

"BioMed Central will be the most significant development for disseminating the results of biomedical research in our lifetime. "

Sir Paul Nurse, Cancer Research UK

Your research papers will be:

- available free of charge to the entire biomedical community

- peer reviewed and published immediately upon acceptance

- cited in PubMed and archived on PubMed Central

- yours - you keep the copyright
BioMedcentral 